\title{
Central Serotonergic Activity is Related to the Aggressive Behaviors of Alzheimer's Disease
}

Krista L. Lanctôt, Ph.D., Nathan Herrmann, M.D., F.R.C.P.C., Goran Eryavec, M.D., F.R.C.P.C., Robert van Reekum, M.D., F.R.C.P.C., Kenton Reed, Ph.D., and Claudio A. Naranjo, M.D.

The clinical correlates of reduced serotonin (5-HT) in Alzheimer's disease $(A D)$ remain unknown. The hypothesis of this study was that altered central serotonergic activity is related to aggression in $A D$. Twenty-two institutionalized, nondepressed elderly (12 M/10 F, mean age \pm SD: $82.2 \pm$ 6.4) with probable $A D$, severe cognitive impairment $(M M S E=4.1 \pm 4.7)$ and significant behavioral disturbance (Neuropsychiatric Inventory (NPI) score $\geqslant 8$ ) were studied. The prolactin (PRL) response to d,lfenfluramine (60 mg p.o.) was used as an index of central serotonergic function. The NPI aggression score, NPI irritability score, and Behavioral Pathology in $A D$ aggression score were positively correlated to prolactin concentrations following fenfluramine challenge $\left(r_{S}=.61\right.$, $\mathrm{p}=.003 ; r_{S}=.53, \mathrm{p}=.012 ;$ and $r_{S}=.47, \mathrm{p}=.029$ respectively). In addition, aggressive patients showed a

KEY WORDS: Serotonin; Aggression; Behavioral and psychological symptoms of dementia; Alzheimer's disease; Neurochemical pathology

From the Psychopharmacology Research Program and Department of Psychiatry, Sunnybrook and Women's College Health Sciences Centre (KLL, NH, CAN), and Departments of Pharmacology (KLL, CAN), Psychiatry (KLL, NH, GE, RvR, CAN), and Medicine (NH, CAN), University of Toronto, Seniors' Health Centre, North York General Hospital (GE), Department of Psychiatry (RvR) and Kunin-Lunenfeld Applied Research Unit (KLL, RvR), Baycrest Centre for Geriatric Care, and Psychopharmacology Laboratory, Queen Street Mental Health Centre (KR), Toronto, Ontario, Canada.

Address correspondence to: Dr. K.L. Lanctôt, Department of Psychiatry, Sunnybrook and Women's College Health Sciences Centre, 2075 Bayview Avenue, Room FG-05, Toronto, Ontario M4N 3M5, Canada. Tel: (416) 480-6100 ext. 2241; Fax: (416) 480-6022; E-mail: Krista.Lanctot@swchsc.on.ca

Received December 19, 2001; revised March 18, 2002; accepted March 25, 2002.

Online publication: $3 / 27 / 02$ at www.acnp.org/citations/ Npp032702275. greater mean PRL increase ( $\%$ baseline) $(215 \pm 60, n=11)$ than nonaggressive subjects $(123 \pm 54, n=11)(\mathrm{p}=.01$, 2-tailed $t$-test). The change in PRL concentration depended on level of cognitive impairment $(\mathrm{p}=.0004)$ and the gender $x$ aggression interaction $(\mathrm{p}=.015)$ with the overall regression model accounting for $74 \%$ of the variance ( $r=$ $0.86, F=11.9, \mathrm{p}=.0001)$. Female aggressive subjects with less cognitive impairment had the largest response to fenfluramine challenge. These results suggest a complex link between aggression in $A D$ and central serotonergic dysfunction having interactions with gender and cognitive impairment.

[Neuropsychopharmacology 27:646-654, 2002]

(C) 2002 American College of Neuropsychopharmacology. Published by Elsevier Science Inc.

The behavioral and psychological symptoms of dementia (BPSD) include delusions, hallucinations, aggression, activity disturbance (e.g., wandering), affective disturbances, anxieties, diurnal rhythm disturbances and apathy (Raskind 1993; Cummings et al. 1994; Sclan et al. 1996). These behaviors are common, and have negative impacts on both the patient and the caregiver (Cohen et al. 1993; Cohen-Mansfield and Billig 1986). Despite this known importance, the neurobiology underlying agitation and aggression in AD remains to be elucidated, complicating rational treatment attempts.

Alzheimer's disease (AD) is associated with an extensive serotonergic deficit (Adolffson et al. 1979; Arai et al. 1984; Cross et al. 1984; Mann and Yates 1983; Yamamoto and Hirano 1985). As serotonin (5-HT) generally plays an inhibitory role on motivated behaviors and other neurotransmitter systems, loss of inhibiting tone from the 5-HT system may be important in BPSD 
(Herrmann and Lanctôt 1997; Lanctôt et al. 2001). In fact, the serotonergic system is involved in many psychobiological functions such as aggression, anxiety, depression, sleep, sexual behavior, appetite, anxiety, learning, aversion and psychosis (Dubovsky and Thomas 1995) that are relevant to BPSD. Furthermore, reduced 5-HT has been associated with hostility, impulsivity and aggression in other, non-demented psychiatric populations (Coccaro and Astill 1990; Linnoila and Virkkunen 1992; van Praag 1991). Three post-mortem studies have addressed the relationship between serotonin and aggression finding both decreased serotonin and it metabolite (Palmer et al. 1988), decreased serotonin 5- $\mathrm{HT}_{2}$ receptors (Procter et al. 1992) and no relationship (Chen et al. 1996). The in vivo functional significance of underlying dysfunctions in serotonergic neurotransmission with respect to behaviors and their potential for treatment is unknown.

Open label trial treatment with selective serotonin reuptake inhibitors (SSRIs) such as alaproclate (Bergman et al. 1983), sertraline (Burke et al. 1997; Burke et al. 1994) and citalopram (Pollock et al. 1997), and the 5-HT $1 \mathrm{~A}$ partial agonist buspirone (Herrmann and Eryavec 1993) have been associated with improvements in BPSD in a high proportion of patients. Randomized controlled trials with the SSRIs (Auchus and Bissey-Black 1997; Burke et al. 1994; Cutler et al. 1985; Dehlin et al. 1985; Katona et al. 1998; Lanctôt et al. 2002; Nyth and Gottfries 1990; Olafsson et al. 1992; Pollock et al. 2002; Taragano et al. 1997), buspirone (Cantillon et al. 1996; Lawlor et al. 1994) and the serotonin norepinephrine reuptake inhibitor trazodone (Lawlor et al. 1994; Sultzer et al. 1997) have also been performed for the treatment of BPSD with more equivocal results. Of the SSRIs, citalopram, which has the highest selectivity for serotonin versus norepinephrine (Hyttel 1994), shows the greatest efficacy in randomized controlled trials (Nyth and Gottfries 1990; Pollock et al. 2002). This clinical evidence, albeit indirect, is supportive of a link between serotonergic dysfunction and some BPSD.

The hypothesis of this study was that reduced central serotonergic activity is etiologically related to aggression in patients with AD. To test this hypothesis, central serotonergic tone (e.g., the prolactin (PRL) response to the 5-HT releaser-uptake inhibitor fenfluramine) in demented patients with aggressive behaviors was compared with that of demented patients without aggressive behaviors.

\section{METHODS}

\section{Subjects}

All subjects were inpatients in the long-term care facilities associated with three hospitals. The Research Ethics Board of each hospital approved the study. After com- plete description of the study, the legal substitute decision-maker for each subject provided written informed consent.

Each subject received a comprehensive diagnostic assessment including physical, neurological, and psychiatric examinations. To be included in the study, patients had to meet the DSM-IV criteria for primary degenerative dementia (American Psychiatric Association 1994) and the NINCDS-ADRDA criteria for probable Alzheimer's disease (McKhann et al. 1984) of at least one year's duration. As well, patients had to have significant behavioral problems as demonstrated by a score of at least eight on the Neuropsychiatric Inventory (NPI) (Cummings et al. 1994), be at least 55 years of age and score less than 24 on the Mini-Mental State Examination (MMSE) (Folstein and Folstein 1975). Patients were recruited so that half of them had a clinical notation of aggression and showed aggressive behaviors and the remainder were nonaggressive. Patients were excluded if they had clinical or laboratory evidence of a significant medical illness or other medical/ neurological condition which could diminish cognitive function, a Hachinski ischemic score $>3$ (Hachinski et al. 1975), or a brain computed tomographic (CT) scan that could not be interpreted as consistent with AD. In addition patients were excluded if they had evidence of significant cardiovascular disease or hypertension ( $>160$ / $100 \mathrm{mmHg}$ ), a premorbid or current psychiatric diagnosis (including major depression), contraindications to receiving fenfluramine, or administration of a depot antipsychotic within one treatment cycle of the baseline assessment.

\section{Study Design}

Patients who met the study entrance criteria at the screening visit as described above began a washout, during which all psychotropic and antiparkinsonian medications were discontinued. This washout was necessary in anticipation of initiating a new psychotropic trial. The length of washout was approximately one week, based on five half-lives of the psychotropic medication (or its active metabolite). After the washout, patients were given a fenfluramine challenge test to assess central serotonergic function.

Patients were assessed twice: at a screening visit (baseline) and after washout (test day). Patients were assessed for behaviors, cognition, function and depression. Behavioral disturbances were the primary outcome variable and were assessed with the Neuropsychiatric Inventory (NPI) (Cummings et al. 1994) that assesses 10 behavioral disturbances occurring in dementia patients: delusions, hallucinations, dysphoria, anxiety, agitation/aggression, euphoria, disinhibition, irritability/lability, apathy, and aberrant motor activity. Depression was assessed with the Cornell Scale for De- 
pression in Dementia (Cornell) (Alexopoulos et al. 1988). Cognition was measured with the MMSE (Folstein and Folstein 1975). Functional ability was measured with the Functional Assessment Staging (FAST) scale, which measures functional loss in AD (Reisberg 1988). Clinical Global Impression (CGI) for the overall severity of the behavioral disturbances was assessed by both the physician and primary nurse. Secondary behavior scales included the Behavioral Pathology in Alzheimer's Disease (BEHAVE-AD) rating scale (Sclan et al. 1996) to measure overall psychopathology and the Cohen-Mansfield Agitation Inventory (CMAI) (CohenMansfield and Billig 1986) which rates the frequencies of 29 types of agitated behaviors on a 7-point scale. Except for fenfluramine, no psychotropic medication was administered during the trial. There was provision for the administration of lorazepam if needed during washout, but use could not exceed four times per week.

\section{Fenfluramine Challenge Test}

While there are a variety of neuroimaging techniques available to visualize the serotonergic system in vivo, these are impractical in highly agitated individuals with severe cognitive impairment. The level of agitation in this group of severely impaired institutionalized individuals makes it highly unlikely that they would tolerate 60 or more minutes of lying motionless in a PET or SPECT scanner. Neuroendocrine challenge studies are advantageous in that they are minimally invasive, require cooperation for less time, and can be performed in the patient's familiar environment.

Changes in the plasma levels of anterior pituitary hormones in response to various serotonergic agonists have been widely used to study brain serotonergic function in psychiatric disorders (Risch et al. 1981). In this study, the prolactin response to $d, l$-fenfluramine challenge was used. Fenfluramine has been associated with cardiac valvulopathy after prolonged therapy (Connolly et al. 1997), but not single dose use, and behavioral side-effects have not been reported in patients with dementia (Mintzer et al. 1998). Food and fluids other than water were not permitted after midnight on the night before the fenfluramine challenge test day. On the morning of the test day patients were served a light breakfast and they were provided with juice and light snacks throughout the test period as both dehydration and hypoglycemia can affect prolactin secretion. $\mathrm{Pa}-$ tients were encouraged to remain awake, recumbent and relaxed throughout the procedure as sleep, stress, and exercise can also alter prolactin secretion.

Tests commenced at approximately 8:00 A.M. and were conducted in the patients' own rooms. Two blood samples were obtained $15 \mathrm{~min}$ apart for determination of baseline prolactin concentration. Five minutes after the second blood sample (time 0) $60 \mathrm{mg}$ of $d, l$-fenflu- ramine was administered orally. Blood samples for prolactin concentration were obtained 3 and $4 \mathrm{~h}$ later. Peak concentration is expected at $4 \mathrm{~h}$, but the effect should be significant from 2 to $8 \mathrm{~h}$ after fenfluramine administration (Quattrone et al. 1983). The blood samples were collected into tubes containing aprotonin (Trasylol) to prevent degradation of hormones by plasma proteases. Samples were kept cool and serum was separated by centrifugation $(1,000 \times \mathrm{g}$ for $10 \mathrm{~min})$ within $2 \mathrm{~h}$ of being drawn. Serum was refrigerated until the determination of hormone levels by a two-site chemiluminometric (sandwich) immunoassay.

Blood samples for determination of plasma fenfluramine and norfenfluramine (active metabolite) levels were also collected at time 0 and $4 \mathrm{~h}$ after fenfluramine administration. These samples were collected into heparin coated tubes, refrigerated, and centrifuged within $2 \mathrm{~h}$. Plasma was stored at $-20^{\circ} \mathrm{C}$. Concentrations of fenfluramine and norfenfluramine were determined by GCMS (gas chromatography mass spectography) by one of the authors who was blind to aggressiveness status of the patients (KR).

\section{Data Analysis}

Baseline plasma prolactin concentration (the mean prolactin concentration of the two blood samples taken before fenfluramine administration) and peak prolactin concentration (the maximum measured concentration after fenfluramine administration) were calculated for each patient. Prolactin response was calculated as percent change from baseline (peak prolactin concentration/baseline prolactin concentration) to adjust for differences in baseline prolactin. Relationships between baseline prolactin concentration, prolactin response, aggression and scores on the assessment instruments were determined using Spearman's rank correlation tests and multiple regression analyses. Aggression was also considered as a dichotomous variable. On the basis of the NPI aggression/agitation subscale (maximum 12) after washout, patients who scored 6 or higher on the NPI aggression subscale (at least once per week and at least moderate severity) at baseline were classified as "aggressive" ( $n=11)$, while those who scored 4 or lower were classified as "non-aggressive" $(n=11)$. Prolactin response of the aggressive group of patients were compared with those of the non-aggressive group using independent samples $t$-tests.

\section{RESULTS}

\section{Study Subjects}

Forty-one patients who met preliminary inclusion criteria were referred or identified. Consent to participate was obtained for 26 of these patients. Of those 26, three 
patients dropped out before the fenfluramine challenge test and a fourth patient did not complete it because of problems drawing blood. Therefore, 22 patients completed the fenfluramine test day.

\section{Baseline Characteristics}

The baseline characteristics of the patients are shown in Table 1 . The 22 patients were severely impaired as shown by both the MMSE and the FAST. They had no notable depression as demonstrated by their low scores on the Cornell scale for depression in dementia. There were no significant differences between the groups in any of the subject characteristics (Table 1), but the groups differed in level of aggression (Table 2). Table 3 shows the other behaviors that were present at the time of fenfluramine challenge.

\section{Prolactin Response to Fenfluramine Challenge}

Relationship with Aggression. The mean prolactin concentrations as a percent of baseline are shown in Figure 1, panel A. The aggressive group had a significantly greater increase in prolactin following fenfluramine administration $(215 \pm 60 \%)$ than the non-aggressive group $(123 \pm 54 \%)(p<.01)$.
The relationship between prolactin response following fenfluramine challenge and aggression was confirmed by significant correlations between prolactin response (expressed as percentage of baseline) and scores on the Neuropsychiatric Inventory aggression/agitation subscale $\left(\mathrm{r}_{\mathrm{s}}=0.61, p=.003\right)$ (Figure 2) and irritability subscale $\left(\mathrm{r}_{\mathrm{S}}=.53, p=.012\right)$ and the aggressiveness axes of the BEHAVE-AD $\left(\mathrm{r}_{\mathrm{s}}=0.47, p=.03\right)$. Score on the CMAI aggressiveness subscales (sum of verbal/ aggressive and physical/aggressive axes) was not significantly correlated to prolactin response.

Specificity for Aggression. Although overall level of psychopathology (NPI total) was also correlated with prolactin response, the aggression subscale of the NPI accounted for more variability (Table 3). Furthermore, there were no correlations between prolactin response following fenfluramine challenge and the nonaggressive subscales of the NPI except irritability (Table 3).

Gender Effect. There were significant differences between the responses of the male and female subjects in the fenfluramine challenge test. Female aggressive subjects had a more rapid and robust increase in prolactin concentration as a percentage of baseline (216 $\pm 70 \%$, $\mathrm{n}=4)$ than nonaggressive females $(97 \% \pm 40, \mathrm{n}=6)$. In contrast, while the aggressive males had a robust in-

Table 1. Demographics, Patient Characteristics at Baseline and Fenfluramine and Norfenfluramine Concentrations $(\mathrm{n}=22)$

\begin{tabular}{|c|c|c|c|c|}
\hline & $\begin{array}{c}\text { Total } \\
(n=22)\end{array}$ & $\begin{array}{l}\text { Nonaggressive } \\
\quad(n=11)\end{array}$ & $\begin{array}{l}\text { Aggressive } \\
(n=11)\end{array}$ & $p$-value ${ }^{\dagger}$ \\
\hline \multicolumn{5}{|l|}{ Age } \\
\hline $\begin{array}{l}\text { mean } \pm S D \\
\text { (range) }\end{array}$ & $\begin{array}{l}82.2 \pm 6.4 \\
\quad(74,95)\end{array}$ & $\begin{array}{l}82.3 \pm 5.6 \\
(74,95)\end{array}$ & $\begin{array}{l}82.1 \pm 7.6 \\
\quad(75,93)\end{array}$ & .93 \\
\hline Gender & $12 \mathrm{M} / 10 \mathrm{~F}$ & $5 \mathrm{M} / 6 \mathrm{~F}$ & $7 \mathrm{M} / 4 \mathrm{~F}$ & .39 \\
\hline \multicolumn{5}{|l|}{ Mini-mental state (MMSE) } \\
\hline $\begin{array}{l}\text { mean } \pm \mathrm{SD} \\
\text { (range) }\end{array}$ & $\begin{array}{l}4.1 \pm 4.7 \\
(0,18)\end{array}$ & $\begin{array}{l}2.4 \pm 2.2 \\
(0,6)\end{array}$ & $\begin{array}{l}5.7 \pm 6.0 \\
(0,18)\end{array}$ & $.11^{*}$ \\
\hline \multicolumn{5}{|l|}{ Functional staging (FAST) } \\
\hline $\begin{array}{l}\text { median score } \\
\text { (range) }\end{array}$ & $\begin{array}{c}6 d \\
6 a-7 b\end{array}$ & $\begin{array}{c}6 d \\
6 a-7 b\end{array}$ & $\begin{array}{c}6 d \\
6 b-7 a\end{array}$ & \\
\hline \multicolumn{5}{|l|}{ Cornell depression scale } \\
\hline $\begin{array}{l}\text { mean } \pm \text { SD } \\
\text { (range) }\end{array}$ & $\begin{array}{c}5.5 \pm 3.2 \\
(1,12)\end{array}$ & $\begin{array}{l}4.6 \pm 3.1 \\
(1,12)\end{array}$ & $\begin{array}{c}6.3 \pm 3.2 \\
(2,12)\end{array}$ & .21 \\
\hline \multicolumn{5}{|l|}{ Years AD diagnosis } \\
\hline $\begin{array}{l}\text { mean } \pm \mathrm{SD} \\
\text { (range) }\end{array}$ & $\begin{array}{l}5.5 \pm 2.5 \\
(2,10)\end{array}$ & $\begin{array}{l}5.6 \pm 2.3 \\
(2,9)\end{array}$ & $\begin{array}{l}5.4 \pm 2.8 \\
(2,10)\end{array}$ & $>.5$ \\
\hline \multicolumn{5}{|l|}{ Years institutionalized } \\
\hline $\begin{array}{l}\text { mean } \pm \mathrm{SD} \\
\text { (range) }\end{array}$ & $\begin{array}{c}1.77 \pm 1.48 \\
(0,6)\end{array}$ & $\begin{array}{c}1.45 \pm 1.21 \\
(0,3)\end{array}$ & $\begin{array}{l}2.09 \pm 1.70 \\
(0,6)\end{array}$ & $>0.1$ \\
\hline Psychotropics before washout ${ }^{* *}$ & 19 & 9 & 10 & $>.9$ \\
\hline $\begin{array}{l}\text { Fenfluramine concentration } \\
\quad(\mathrm{nm} / \mathrm{L}) \text { mean } \pm \mathrm{SD}\end{array}$ & \multicolumn{3}{|c|}{ Fenfluramine concentration } & $.88(n=21)$ \\
\hline $\begin{array}{l}\text { Norfenfluramine concentration } \\
\quad(\mathrm{nm} / \mathrm{L}) \text { mean } \pm \mathrm{SD}\end{array}$ & $45 \pm 20$ & $49 \pm 24$ & $40 \pm 16$ & $.35(\mathrm{n}=19)$ \\
\hline
\end{tabular}

${ }^{\dagger} t$-test or chi-square as appropriate, ${ }^{*}$ adjusted for unequal variances, ${ }^{* *}$ number of patients taking antipsychotics, sedative hypnotics or antidepressants immediately prior to washout, $\mathrm{AD}=$ Alzheimer's disease, $\mathrm{BPSD}=$ behavioral disorders, $\mathrm{SD}=$ standard deviation. Note: sample sizes are as noted at the top of each column, exceptions indicated. 
Table 2. Aggression after Washout in 22 Study Subjects

\begin{tabular}{lccc}
\hline Aggression scale & $\begin{array}{c}\text { Aggressive } \\
(\mathbf{n}=\mathbf{1 1})\end{array}$ & $\begin{array}{c}\text { Non-aggressive } \\
(\mathbf{n}=\mathbf{1 1})\end{array}$ & $\boldsymbol{p}$-value \\
\hline $\begin{array}{l}\text { NPI agitation/ } \\
\quad \text { aggression subscale }\end{array}$ & $8.7 \pm 2.7$ & $1.7 \pm 1.7$ & $<.001$ \\
$\begin{array}{l}\text { NPI irritability subscale } \\
\text { BEHAVE-AD }\end{array}$ & $6.5 \pm 3.3$ & $1.2 \pm 1.4$ & $<.001$ \\
$\quad \begin{array}{l}\text { aggression subscale } \\
\text { CMAI verbal and } \\
\text { physical aggression }\end{array}$ & $6.5 \pm 2.1$ & $2.6 \pm 1.7$ & $<.001$ \\
\hline
\end{tabular}

crease in prolactin concentration $(215 \% \pm 60, \mathrm{n}=7)$, nonaggressive males also had a small increase in prolactin concentration $(155 \% \pm 53, \mathrm{n}=5)$ (Figure 1, panel B). Regression analysis confirmed that the prolactin response to fenfluramine challenge was significantly different for males and females $(p=.003)$ and also the effect of gender was different for aggressive and non-aggressive patients, and the effect of aggression was different for males and females ( $p=.0036$ for interaction in regression analysis). The overall model was significant ( $p=$ $.006)$ and accounted for $49 \%$ of the variance $(r=0.70)$.

Secondary Outcome Variables. Prolactin response was not significantly correlated with baseline measures of sedation, Clinical Global Impression by caregiver or investigator or body weight (Spearman rank rho, all $p>.3$ ). Prolactin response was however, correlated with baseline scores on the Cornell scale for depression in dementia $\left(\mathrm{r}_{\mathrm{S}}=.47, p=.03\right)$, perhaps reflecting the Cornell's assessment of symptoms of agitation, and MMSE $\left(\mathrm{r}_{\mathrm{S}}=.54, p=.01\right)$. In a regression analysis, MMSE was a strong predictor of prolactin response $(p=.0004)$. In the same regression model, there was again a significant interaction between the effects of gender and aggression $(p=.015)$ but neither gender $(p=.08)$ or aggression $(p=$

Table 3. Correlation of NPI Subscales with Prolactin Response in 22 Study Subjects

\begin{tabular}{lccc}
\hline NPI subscale & $\begin{array}{c}\text { Mean } \\
\text { score } \\
(\mathbf{n}=\mathbf{2 2})\end{array}$ & $\begin{array}{c}\text { Spearman } \\
\text { rank rho }\end{array}$ & $p$-value \\
\hline Neuropsychiatric & & & \\
$\quad$ Inventory Total & $18.0 \pm 13.2$ & 0.54 & .01 \\
agitation/ aggression & $5.1 \pm 4.0$ & 0.61 & .003 \\
irritability & $3.9 \pm 3.7$ & 0.53 & .01 \\
delusions & $1.8 \pm 3.4$ & 0.42 & .05 \\
aberrant motor behavior & $3.0 \pm 3.5$ & -0.32 & .15 \\
euphoria & $0.1 \pm 0.2$ & -0.29 & .19 \\
disinhibition & $0.9 \pm 2.1$ & 0.14 & .55 \\
anxiety & $1.6 \pm 3.2$ & 0.12 & .60 \\
apathy & $0.7 \pm 1.9$ & -0.12 & .60 \\
depression & $0.4 \pm 1.1$ & 0.06 & .80 \\
hallucinations & $0.7 \pm 1.9$ & 0.03 & .91 \\
\hline
\end{tabular}

$\mathrm{NPI}=$ neuropsychiatric inventory
.13) alone were significant. The overall model with MMSE was significant $(\mathrm{F}=11.9, p=.0001)$ and accounted for $74 \%$ of the variance $(r=0.86)$.

\section{Plasma Fenfluramine Concentrations}

Blood samples to measure plasma fenfluramine and norfenfluramine concentrations were taken $4 \mathrm{~h}$ after fenfluramine administration (see Table 3 for values). Plasma concentrations of fenfluramine or norfenfluramine were not significantly different for the two levels of aggression, sizes of prolactin response or gender (3-way ANOVA, for main effects $p=.18$ to .74 ). Thus, the relationships between these variables were not due to pharmacokinetic differences between the groups.

\section{Baseline Prolactin Concentration}

Baseline prolactin levels (mean of two pre-fenfluramine concentrations) for the aggressive group $(\mathrm{x} \pm \mathrm{SD}=8.6 \pm$ $3.4 \mu \mathrm{g} / \mathrm{L})$ were significantly lower than those of the non-aggressive group $(16.5 \pm 9.2 \mu \mathrm{g} / \mathrm{L})(p<.05)$. Baseline prolactin concentrations were also correlated with scores on the Neuropsychiatric Inventory aggression/ agitation subscale $\left(\mathrm{r}_{\mathrm{S}}=-0.53, p=.012\right)$ and the aggressiveness axis of the BEHAVE-AD $\left(\mathrm{r}_{\mathrm{S}}=-0.66, p=.001\right)$. There were no significant relationships between baseline prolactin levels and scores on the irritability subscale of the NPI or the aggressiveness subscales of the CMAI.

\section{DISCUSSION}

This study demonstrated that prolactin response to fenfluramine challenge may be directly related to aggression in patients with behavioral disorders and severe cognitive impairment associated with Alzheimer's disease. The finding of a greater prolactin response to fenfluramine challenge in aggressive $\mathrm{AD}$ patients compared with nonaggressive patients is contrary to the results of other studies in males with personality disorders in which impulsive aggression was associated with a blunted prolactin response (Coccaro et al. 1997). However, increased response to fenfluramine challenge was found in impulsive/aggressive polysubstance abusers with antisocial personality disorder, and was interpreted as evidence of post-synaptic supersensitivity to fenfluramine (Fishbein et al. 1989). Importantly, these results are also consistent with those of another group who found a similar relationship between agitation and prolactin response in $10 \mathrm{AD}$ patients (Mintzer et al. 1998). However, that study had a smaller number of patients, did not look at aggression specifically and their sample was predominantly female.

Since fenfluramine releases serotonin from presynaptic stores (van Praag 1991), greater functional sero- 

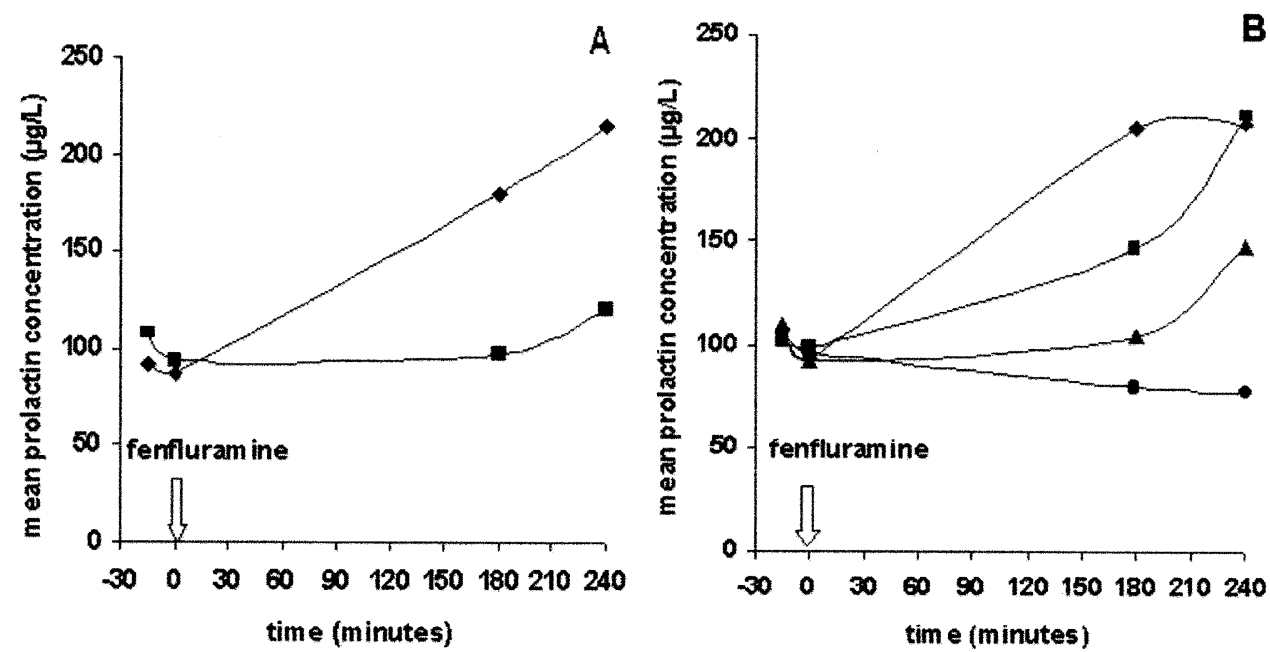

Figure 1. A. Mean prolactin (PRL) concentration as \% of baseline at each time point $(\mathrm{n}=22)$. Baseline prolactin (prefenfluramine) measurements were taken at -15 and $0 \mathrm{~min}$; fenfluramine was given at time 0 and prolactin concentrations were measured 3 and $4 \mathrm{~h}$ after fenfluramine challenge. $\boldsymbol{\nabla}=$ aggressive $(\mathrm{n}=11), \mathbf{\square}=$ nonaggressive $(\mathrm{n}=11)$. B. Mean prolactin (PRL) concentration as \% of baseline-gender effect. Baseline prolactin (prefenfluramine) measurements were taken at -15 and $0 \mathrm{~min}$, fenfluramine was given at time 0 and prolactin concentrations were measured 3 and $4 \mathrm{~h}$ after fenfluramine challenge. $\boldsymbol{\nabla}$ = aggressive females $(\mathrm{n}=4), \boldsymbol{\square}=$ aggressive males $(\mathrm{n}=7), \boldsymbol{\Delta}=$ nonaggressive males $(\mathrm{n}=5), \boldsymbol{0}=$ non aggressive females $(n=6)$.

tonergic responsivity to fenfluramine stimulation, indicated by higher plasma concentrations of prolactin, could reflect either increased intracellular presynaptic availability of 5-HT, changes in postsynaptic receptor sensitivity, or a combination of both. This study in AD patients cannot determine whether the responses of the aggressive patients were high or the responses of the nonaggressive patients were blunted without an agematched control group but it is more plausible that aggressive $\mathrm{AD}$ patients have a functionally hyperresponsive 5-HT system leading to an increased response. This could be due to intrinsic damage to the serotonergic system with compensatory upregulation of the remaining postsynaptic receptors, similar to denervation supersensitivity seen in animals after 5-HT lesioning (Siever et al. 1991). The possibility of denervation supersensitivity in AD is supported by evidence of loss of serotonergic neurons (Mann and Yates 1983; Yamamoto and Hirano 1985), decreased concentrations of 5-HT and its major metabolite in AD (Adolffson et al. 1979; Arai et al. 1984; Cross et al. 1984) and previous neuroendocrine studies (Lawlor et al. 1989; McLoughlin et al. 1994). None of those studies specifically assessed behavioral disorders. There is also evidence that normal aging leads to a blunted prolactin response (McBride et al. 1990), further supporting the hypothesis that aggressive patients had an increased response.

This study also found that the prolactin response to fenfluramine challenge was greater in females than in males. Other studies (Coccaro and Kavoussi 1997; Malone et al. 1996; McBride et al. 1990) have found females to have an elevated response to fenfluramine challenge. Response is postulated to be related to estrogen levels and menstrual cycle in pre-menopausal women (Markianos et al. 1996; O'Keane et al. 1991). However, all females were post-menopausal and only one of the female $\mathrm{AD}$ patients in the present study was on hormone replacement therapy (medroxyprogesterone $2.5 \mathrm{mg} / \mathrm{d}$ ). Females are thought to have increased serotonin function, storage capacity and synthesis compared with males (Charney et al. 1988). These results suggest that gender-related difference in prolactin response persist throughout the life-time and are independent of menstrual status.

Although aggression subscales on the NPI and BEHAVE-AD were correlated with prolactin response results, aggression scores on the CMAI ( $p=.05)$ was not. The Cohen Mansfield Agitation Inventory (CMAI) (Cohen-Mansfield and Billig 1986; Cohen-Mansfield et al. 1989) is designed specifically for nursing home residents and assesses verbal, vocal and motor agitation. It does not have a subscale specifically for aggressive behaviors. Whereas both the NPI and the BEHAVE-AD measure severity of behaviors, the CMAI measures frequency, but not severity. Thus, severe aggression may not be differentiated from mild aggression sufficiently on this scale to be correlated with central serotonergic function. Aggression can occur in a variety of situations (Ware et al. 1990) including only during care ("provoked") and aggression that is more impulsive such as attacking a sleeping patient ("unprovoked"). It may be that only certain types of aggressive behavior, those on 


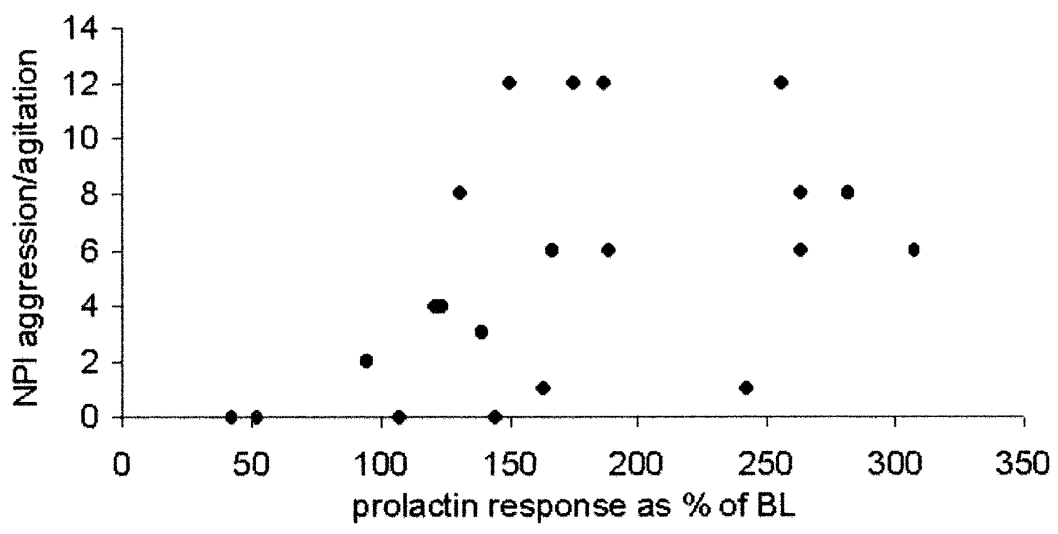

Figure 2. Scatterplot of prolactin response as \% of baseline versus NPI aggression agitation subscale, rho $=0.61, p=.003$.

the more impulsive side, are closely linked to serotonergic function. The NPI irritability scale, which looks at some behaviors that could be considered impulsive, was also correlated with central serotonergic function supporting this.

The concentrations of prolactin prior to fenfluramine challenge were lower in both male and female aggressive AD patients than in nonaggressive AD patients. Prolactin secretion is influenced by several neurotransmitters, neuropeptides and hormones, and by external factors such as medications, stress, sleep and exercise. It is unlikely that prechallenge prolactin could reliably reflect central serotonergic tone.

Of note, in this group of patients, serotonergic hyperresponsivity was greater in patients with less severe cognitive impairment. Although there are no studies looking at the serotonergic system over the course of $\mathrm{AD}$, evidence from post-mortem tissue (where AD has usually run its full course) combined with ante-mortem evidence (where the $\mathrm{AD}$ progression is incomplete) suggests that disruptions in the serotonergic system increase with severity of AD (Palmer 1996). This may have implications for treatment suggesting that the serotonergic system in patients with advanced AD may not be intact enough to respond to serotonergic replacement strategies. Recent evidence from randomized controlled trials are compatible with this interpretation. The randomized placebo-controlled trials that showed positive results with SSRIs in the treatment of behavioral disturbances involved patients with mild $\mathrm{AD}$ (Nyth and Gottfries 1990) and moderate-severe dementia (Pollock et al. 2002). A randomized controlled trial of institutionalized patients with advanced $\mathrm{AD}$ treated with sertraline found that only $36 \%(8 / 22)$ of patients were responders (Lanctôt et al. 2002). Thus, serotonin uptake inhibitors may be more effective earlier in the course of AD.

In this study, patients were free of psychotropic medications for at least one week prior to fenfluramine challenge, and this interval was greater than five halflives of their previous psychotropic medications. De- spite washout, there is a possibility that prior use of psychotropic medications confounded fenfluramine challenge results. In this population, since both aggressive and nonaggressive patients had BPSD, all patients had recent histories of psychotropic drug utilization except three (two nonaggressive, one aggressive). While the impact of previous drug use on the CNS cannot be measured, this potential confounder was present in both aggressives and nonaggressives.

\section{CONCLUSIONS}

In conclusion, the results of this study suggest that altered central 5-HT activity is related to aggression in AD patients. The increased prolactin response to fenfluramine may be evidence for serotonergic hyperresponsivity in these patients, and suggests the possibility that serotonergic strategies may be efficacious for this condition. However, if the denervation supersensitivity hypothesis is correct, exacerbation of aggression may initially be seen with such treatment, and decreases on aggression would be expected only as the supersensitivity decreased. Furthermore, patients with advanced Alzheimer's disease may not benefit from serotonergic replacement therapies. This study links aggression with serotonergic differences in vivo and as such contributes to the knowledge of the neurobiology of behavioral disorders associated with dementia.

\section{ACKNOWLEDGMENTS}

This study was supported by Physicians' Services Incorporated Foundation. Dr. Lanctôt was supported by the Alzheimer Society of Canada Research Program. Dr. Lanctôt and Dr. van Reekum are supported by the Kunin-Lunenfeld Applied Research Unit.

The authors gratefully acknowledge the assistance of Dr. V. Ozdemir, Dr. R.W. Shulman, Ms. R. Croxford, and Ms. K.E. Bremner. 


\section{REFERENCES}

Adolffson R, Gottfries CG, Roos BE, Winblad B (1979): Changes in brain catecholamines in patients with dementia of Alzheimer type. Brit J Psychiat 135:216-233

Alexopoulos GS, Abrams RC, Young RC, Shamoian CA (1988): Cornell scale for depression in dementia. Biol Psychiatry 23:271-284

American Psychiatric Association (1994): Diagnostic and Statistical Manual of Mental Disorders. Washington, DC, American Psychiatric Association

Arai H, Kosaka K, Iiziku R (1984): Changes of biogenic amines and their metabolites in postmortem brains from patients with Alzheimer-type dementia. J Neurochem 43:388-393

Auchus A, Bissey-Black C (1997): Pilot study of haloperidol, fluoxetine, and placebo for agitation in Alzheimer's disease. J Neuropsychiat Clin Neurosci 9:591-593

Bergman I, Brane G, Gottfries CG, Jostell KG, Karlsson I, Svennerholm L (1983): Alaproclate: a pharmacokinetic and biochemical study in patients with dementia of Alzheimer type. Psychopharmacology (Berl) 80:279-283

Burke WJ, Dewan V, Wengel SP, Roccaforte WH, Nadolny GC, Folks DG (1997): The use of selective serotonin reuptake inhibitors for depression and psychosis complicating dementia. Int J Geriatr Psychiatry 12:519-525

Burke WJ, Folks DG, Roccaforte WH, Wengel SP (1994): Serotonin reuptake inhibitors for the treatment of coexisting depression and psychosis in dementia of the Alzheimer type. Am J Geriatr Psychiatry 2:352-354

Cantillon M, Brunswick R, Molina D, Bahro M (1996): Buspirone vs. haloperidol. A double-blind trial for agitation in a nursing home population with Alzheimer's disease. Am J Geriatr Psychiatry 4:263-267

Charney DS, Goodman WK, Price LH, Woods SW, Rassmussen SA, Heninger GR (1988): Serotonin function in obsessive-compulsive disorder. Arch Gen Psychiatry 45:177-185

Chen CPL-H, Alder JT, Bowen DM, Esiri MM, McDonald B, Hope T, Jobst KA, Francis PT (1996): Presynaptic serotonergic markers in community-acquired cases of Alzheimer's disease: correlations with depression and neuroleptic medication. J Neurochem 66:1592-1598

Coccaro EF, Astill JL (1990): Central serotonergic function in parasuicide. Prog Neuro-Psychopharmacol \& Biol Psychiat 14:663-674

Coccaro EF, Kavoussi RJ (1997): Fluoxetine and impulsive aggressive behavior in personality-disordered subjects. Arch Gen Psychiatry 4:1081-1088

Coccaro EF, Kavoussi RJ, Cooper TB, Hauger RL (1997): Central serotonin activity and aggression: inverse relationship with prolactin response to $d$-fenfluramine, but not CSF 5-HIAA concentration, in human subjects. Am J Psychiatry 154:1430-1435

Cohen CA, Gold DP, Shulman KI, Wortley JT, Mcdonald G, Wargon M (1993): Factors determining the decision to institutionalize dementing individuals: a prospective study. Gerontologist 33:714-720

Cohen-Mansfield J, Billig N (1986): Agitated behaviors in the elderly I. A conceptual review. J Am Geriatr Soc 34:711-721
Cohen-Mansfield J, Marx MS, Rosenthal AS (1989): A description of agitation in a nursing home. J Gerontol 44:M77-M84

Connolly HM, Crary JL, McGoon MD, Hensrud DD, Edwards BS, Edwards WD, Schaff HV (1997): Valvular heart disease associated with fenfluramine-phentermine. N Engl J Med 337:581-588

Cross AJ, Crow TJ, Ferrier IN, Johnson JA, Bloom SR, Corsellis JAN (1984): Serotonin receptor changes in dementia of the Alzheimer type. J Neurochem 43:1574-1581

Cummings JL, Mega M, Gray K, Rosenberg-Thompson S, Carusi DA, Gornbein J (1994): The Neuropsychiatric Inventory: comprehensive assessment of psychopathology in dementia. Neurology 44:2308-2314

Cutler NR, Haxby J, Kay AD, Narang PK, Lesko LJ, Costa JL, Ninos M, Linnoila M, Potter WZ, Renfrew JW, Moore AM (1985): Evaluation of zimeldine in Alzheimer's disease: cognitive and biochemical measures. Arch Neurol 42:744-748

Dehlin O, Hedenrud B, Jansson P, Nörgård J (1985): A double-blind comparison of alaproclate and placebo in the treatment of patients with senile dementia. Acta Psychiatr Scand 71:190-196

Dubovsky SL, Thomas M (1995): Serotonergic mechanisms and current and future psychiatric practice. J Clin Psychiatry 56:38-48

Fishbein DH, Lozovsky D, Jaffe J (1989): Impulsivity, aggression, and neuroendocrine responses to serotonergic stimulation in substance abusers. Biol Psychiatry 25: 1049-1066

Folstein MF, Folstein SE (1975): "Mini-mental state" A practical method for grading the cognitive state of patients for the clinician. J Psychiat Res 12:189-198

Hachinski VC, Iliff LD, Zilhka E, Du Boulay GH, McAllister VL, Marshall J, Ross Russell RW, Symon L (1975): Cerebral blood flow in dementia. Arch Neurol 32:632-637

Herrmann N, Eryavec G (1993): Buspirone in the management of agitation and aggression associated with dementia. Am J Geriatric Psychiat 1:249-253

Herrmann N, Lanctôt KL (1997): From transmitters to treatment: The pharmacotherapy of behavioral disturbances in dementia. Can J Psychiatry 42:51S-64S

Hyttel J (1994): Pharmacological characterization of selective serotonin reuptake inhibitors (SSRIs). Int Clin Psychopharmacol 9:19-26

Katona C, Hunter B, Bray J (1998): A double-blind comparison of the efficacy and safety of paroxetine and imipramine in the treatment of depression with dementia. Int J Geriat Psychiat 13:100-108

Lanctôt KL, Herrmann N, Eryavec G, van Reekum G, Naranjo CA (2002): Gender, aggression and serotonergic function are associated with response to sertraline for behavioral disturbances in Alzheimer's disease. Int J Ger Psychiatry 17:531-541

Lanctôt KL, Herrmann N, Mazzotta P (2001): Role of serotonin in the behavioral and psychological symptoms of dementia. J Neuropsychiatry Clin Neurosci 13:5-21

Lawlor BA, Radcliffe J, Molchan SE, Martinez RA, Hill JL, Sunderland T (1994): A pilot placebo-controlled study 
of trazodone and buspirone in Alzheimer's disease. Int J Geriatr Psychiatry 9:55-59

Lawlor BA, Sunderland T, Mellow AM, Hill JL, Molchan SE, Murphy DL (1989): Hyperresponsivity to the serotonin agonist $m$-chlorophenylpiperazine in Alzheimer's disease. Arch Gen Psychiatry 46:542-549

Linnoila VMI, Virkkunen M (1992): Aggression, suicidality, and serotonin. J Clin Psychiatry 53:46-51

Malone KM, Corbitt EM, Li S, Mann JJ (1996): Prolactin response to fenfluramine and suicide attempt lethality in major depression. Br J Psychiatry 168:324-329

Mann DMA, Yates PO (1983): Serotonin nerve cells in Alzheimer's disease. J Neurol Neurosurg Psychiatry 46:96-98

Markianos M, Lykouras L, Stefanis C (1996): Prolactin and TSH responses to TRH and to ECT in pre-and postmenopausal women with major depression. Biol Psychiatry 40:403-406

McBride PA, Tierney H, DeMeo M, Chen JS, Mann JJ (1990): Effects of age and gender on CNS serotonergic responsivity in normal adults. Biol Psychiatry 27:1143-1155

McKhann G, Drachman D, Folstein M, Katzman R, Price D, Stadlan EM (1984): Clinical diagnosis of Alzheimer's disease: Report of the NINCDS-ADRDA Work Group under the auspices of Department of Health and Human Services Task Force on Alzheimer's Disease. Neurology 34:939-944

McLoughlin DM, Lucey JV, Dinan TG (1994): Central serotonergic hyperresponsivity in late-onset Alzheimer's disease. Am J Psychiatry 151:1701-1703

Mintzer J, Mintzer-Brawman O, Mirski DF, Unger R, Nietert P, Meeks A, Sampson R (1998): Fenfluramine challenge test as a marker of serotonin activity in patients with Alzheimer's dementia and agitation. Biol Psychiatry 44:918-921

Nyth AL, Gottfries CG (1990): The clinical efficacy of citalopram in treatment of emotional disturbances in dementia disorders. A Nordic multicentre study. Brit J Psychiatr 157:894-901

O'Keane V, O'Hanlon M, Webb M, Dinan T (1991): d-Fenfluramine/prolactin response throughout the menstrual cycle: evidence for an oestrogen-induced alteration. Clin Endocrinol 34:289-292

Olafsson K, Jorgensen S, Jensen HV, Bille A, Arup P, Andersen J (1992): Fluvoxamine in the treatment of demented elderly patients: a double-blind, placebo-controlled study. Acta Psychiatr Scand 85:453-456

Palmer AM (1996): Neurochemical studies of Alzheimer's disease. Neurodegeneration 5:381-391

Palmer AM, Stratman GC, Procter AW, Bowen DM (1988): Possible neurotransmitter basis of behavioral changes in Alzheimer's disease. Ann Neurol 23:616-620

Pollock BG, Mulsant BH, Rosen J, Sweet RA, Mazumdar S, Bharucha A, Marin R, Jacob NJ, Huber KA, Kastango KB, Chew ML (2002): Comparison of citalopram, perphenazine, and placebo for the acute treatment of psy- chosis and behavioral disturbances in hospitalized, demented patients. Am J Psychiatry 159:460-465

Pollock BG, Mulsant BH, Sweet R, Burgio LD, Kirshner MA, Shuster K, Rosen J (1997): An open pilot study of citalopram for behavioral disturbances of dementia. Plasma levels and real-time observations. Am J Geriat Psychiat 5:70-78

Procter AW, Francis PT, Stratmann GC, Bowen DM (1992): Serotonergic pathology is not widespread in Alzheimer patients without prominent aggressive symptoms. Neurochemical Res 17:917-922

Quattrone A, Tedeschi G, Aguglia U, Scopacasa F, Di Renzo GF, Annunziato L (1983): Prolactin secretion in man: a useful tool to evaluate the activity of drugs on central 5-hydroxytryptaminergic neurones. Studies with fenfluramine. Br J Clin Pharmacol 16:471-475

Raskind MA (1993): Geriatric psychopharmacology: Management of late-life depression and the non-cognitive behavioral disturbances of Alzheimer's disease. In DL Dunner (ed), The Psychiatric Clinics of North America. Psychopharmacology II, Philadelphia, W.B. Saunders Company, pp 815-827

Reisberg B (1988): Functional assessment staging (FAST). Psychopharmacol Bull 24:653-659

Risch SC, Kalin NH, Murphy DL (1981): Pharmacological challenge strategies: implications for neurochemical mechanisms in affective disorders and treatment approaches. J Clin Psychopahrmacol 1:238-243

Sclan SG, Saillon A, Franssen E, Hugonot-Diener L, Saillon A, Reisberg B (1996): The behavior pathology in Alzheimer's disease rating scale (BEHAVE-AD): reliability and analysis of symptom category scores. Int J Geriat Psychiat 11:819-830

Siever LJ, Kahn RS, Lawlor BA, Trestman RL, Lawrence TL, Coccaro EF (1991): II. Critical issues in defining the role of serotonin in psychiatric disorders. Pharmacol Rev 43:509-525

Sultzer DL, Gray I, Gunay I, Berisford A, Mahler ME (1997): A double-blind comparison of trazodone and haloperidol for treatment of agitation in patients with dementia. Am J Geriatr Psychiatry 5:60-69

Taragano FE, Lyketsos CG, Mangone CA, Allegri RF, Comesaña-Diaz E (1997): A double-blind, randomized, fixeddose trial of fluoxetine vs. amitryiptyline in the treatment of major depression complicating Alzheimer's disease. Psychosomatics 38:246-252

van Praag HM (1991): Serotonergic dysfunction and aggression control. Psychol Med 21:15-19

Ware CJG, Fairburn CG, Hope RA (1990): A communitybased study of aggressive behaviour in dementia. Int $\mathrm{J}$ Geriatr Psychiatry 5:337-342

Yamamoto T, Hirano A (1985): Nucleus raphe dorsalis in Alzheimer's disease: neurofibrillary tangles and loss of large neurons. Ann Neurol 17:573-577 